\title{
Resintered Microstructure Dependence of Mechanical Properties of Alumina Wire Processed by Controlled Fracture Forming
}

\author{
Wen-bo Du ${ }^{\text {1 }}$, Kiyohiko Tatsuzawa ${ }^{\text {1 }}$, Tatsuhiko Aizawa ${ }^{\text {1 } 1}$ and Junji Kihara 2 \\ ${ }^{1}$ Research Center for Advanced Science and Technology, The University of Tokyo, 4-6-1 Komaba, Meguro-ku, Tokyo 153-8904. \\ ${ }^{2}$ School of Humanity for Environment Policy and Technology, Himeji Institute of Technology, 1-1-12 Shinzaikehonmachi, Himeji 670-0092.
}

Received May 15, 2000

\section{SYNOPSIS}

The mechanical properties of the CFF- $\mathrm{Al}_{2} \mathrm{O}_{3}$ wire with respect to the Vickers hardness, the fracture toughness and the fracture/tensile strength have been discussed in the present investigation. Results indicate that the CFF process is valid for fabricating $\mathrm{Al}_{2} \mathrm{O}_{3}$ wire with enhanced mechanical properties. Residual pores in the resintered microstructure are thought to be fatal in determination of the mechanical properties, but the grain size dependence seems to be insensitive. At presence of porosity lower than $2.0 \%$, the fracture of the $\mathrm{CFF}-\mathrm{Al}_{2} \mathrm{O}_{3}$ wire is controlled by the transgranular mode, and its fracture/tensile strength achieves $1.1 \mathrm{GPa}$. However, the intergranular mode becomes dominated, resulting in a decrease in strength if porosity is higher than $2.0 \%$.

KEY WORDS

Alumina Wire, CFF Process, Vickers hardness, Fracture Toughness, Tensile Strength

\section{Introduction}

$\mathrm{Al}_{2} \mathrm{O}_{3}$ fiber/wire can be used to reinforce metal matrix composites (MMCs) because of its high specific strength, high specific Young's modulus and significant chemical stability. A general approach to synthesize $\mathrm{Al}_{2} \mathrm{O}_{3}$ fiber is the sol-gel method ${ }^{1-4)}$, where the aqueous solution is hydrolyzed, condensed and/or ploymerized until an appropriate viscosity for spinning is achieved. However, the organic additives are necessary to raise the viscosity of solution and to improve the spinning characteristics, making this approach difficult to be controlled. The tensile strength and the Young's modulus of the $\mathrm{FP}-\mathrm{Al}_{2} \mathrm{O}_{3}$ fiber were reported to be $1.4 \mathrm{GPa}$ and $380 \mathrm{GPa}$, respectively ${ }^{2}$.

In addition, studies have shown that the mechanical properties of the bulk $\mathrm{Al}_{2} \mathrm{O}_{3}$ are also significantly dependent on its processing routes ${ }^{5,6)}$. The bending strength of pure and high-quality $\mathrm{Al}_{2} \mathrm{O}_{3}$ is about $400-500 \mathrm{MPa}$ by using pressureless sintering, about $500-600 \mathrm{MPa}$ by hot pressing ${ }^{5}$ and about $800 \mathrm{MPa}$ by hot pressing and hot isostatic pressing $(\mathrm{HIP})^{6}$. In these cases, the grain size and the residual pore morphology in the final microstructure are determinative to the mechanical properties. Therefore, experiments are usually performed to avoid the abnormal grain growth and the residual larger pores by using small and homogeneously distributed powder. For example, the colloidal processing is valid for dispersing agglomerates in aqueous solution, and can obtain a green compact with high density and homogeneous microstructure ${ }^{7,8)}$, however, it is complicated and time consuming.

In the previous papers, a novel forming process, which is called the controlled fracture forming (CFF) process, has been reported to be favorable for forming homogeneous green microstructure, and can be used to fabricate ceramic fiber/wire reinforced MMCs. The forming behavior, densification and grain growth of the CFF processed $\mathrm{Al}_{2} \mathrm{O}_{3}$ (CFF- $\mathrm{Al}_{2} \mathrm{O}_{3}$ ) wire have shown that it can be densified to nearly $99 \%$ theoretical density (TD) at a lower temperature such as $1573 \mathrm{~K}$ for $1 \mathrm{~h}$ without abnormal grain growth ${ }^{9-11)}$. In this paper, the effects of the resintered microstructure, especially the residual pore morphology, on the mechanical properties of the $\mathrm{CFF}-\mathrm{Al}_{2} \mathrm{O}_{3}$ wire are systematically investigated with respect to the Vickers hardness, the fracture toughness and the tensile strength.

\section{Experimental Procedure}

The starting powder and the preparation of the presintered $\mathrm{Al}_{2} \mathrm{O}_{3}$ billet were the same as described in Ref. 9. The workpieces in which the presintered $\mathrm{Al}_{2} \mathrm{O}_{3}$ billets $(\sim 80 \%$ TD) had been sheathed into the austenitic stainless steel (JIS SUS-304) were subjected to the controlled swaging by various reduction in area (RA), such as $43 \%, 62 \%, 74 \%$, $85 \%, 92 \%$ and $98 \%$ RA. All extracted and rinsed $\mathrm{Al}_{2} \mathrm{O}_{3}$ 
wire were resintered at 1573 for $1 \mathrm{~h}$ in air, and the one with $98 \%$ RA was further resintered at 1573,1623 and $1673 \mathrm{~K}$ for $0,0.75,1,2,3$, and $5 \mathrm{~h}$ to control grain size and porosity. They were ground on the silicon carbide papers and polished with $0.25 \mu \mathrm{m}$ diamond paste to observe their microstructures by scanning electron micrograph (SEM) after being thermally etched at the temperature of $423 \mathrm{~K}$ lower than the resintering temperature for $2 \mathrm{~h}$. The Vickers hardness and the fracture toughness of these samples were estimated by the indentation, and the loads of $4.9 \mathrm{~N}$ and $98 \mathrm{~N}$ were applied for $15 \mathrm{~s}$ and $30 \mathrm{~s}$, respectively. For each sample, ten indentations were employed to obtain the average value. The Vickers hardness $\left(\mathrm{H}_{\mathrm{v}}\right)$ was calculated by ${ }^{12)}$

$$
\mathrm{H}_{\mathrm{v}}=1854.37 \mathrm{P} / \mathrm{a}^{2}
$$

where $P$ is the applied load, and $a$ the length of the diagonal of indentation. The fracture toughness $\left(\mathrm{K}_{\mathrm{IC}}\right)$ was calculated by ${ }^{13)}$

$$
\mathrm{K}_{\mathrm{IC}}=0.02 \mathrm{E}^{0.5} \mathrm{P}^{0.5} \mathrm{a}^{-0.5}(\mathrm{c} / \mathrm{a})^{-1.5}
$$

Where $E$ is the elastic modulus of $\mathrm{Al}_{2} \mathrm{O}_{3}, 400 \mathrm{MPa}$, and $c$ the half-length of the induced crack. In order to obtain the fracture/tensile strength of the $\mathrm{CFF}-\mathrm{Al}_{2} \mathrm{O}_{3}$ wire, the SUS/ $\mathrm{Al}_{2} \mathrm{O}_{3}$ composite wires $(98 \% \mathrm{RA})$ with the gage length of $100 \mathrm{~mm}$, which had been resintered at the same temperatures and times as described above in vacuum, were measured at the rate of $2 \mathrm{~mm} / \mathrm{min}$. Then, the fracture/tensile strength was calculated by using the rule of mixture (ROM):

$$
\sigma_{\mathrm{c}}=\sigma_{\mathrm{f}} \mathrm{V}_{\mathrm{f}}+\sigma_{\mathrm{m}}\left(1-\mathrm{V}_{\mathrm{f}}\right)
$$

where $\sigma_{\mathrm{c}}$ is the fracture/tensile strength of the composite wire, $\sigma_{\mathrm{f}}$ the fracture/tensile strength of the $\mathrm{CFF}-\mathrm{Al}_{2} \mathrm{O}_{3}$ wire, $\sigma_{\mathrm{m}}$ the fracture/tensile strength of the sheath alloy, SUS 304 , and $V_{f}$ the volume fraction of the wire, $V_{f}=0.24$. In comparison with these calculated results, the fracture/tensile strength of the CFF- $\mathrm{Al}_{2} \mathrm{O}_{3}$ wire was also estimated by an empirical relation: $\sigma_{\mathrm{f}}=\mathrm{H}_{\mathrm{v}} / 20^{14)}$. In addition, the Vickers hardness of the $\mathrm{CFF}-\mathrm{Al}_{2} \mathrm{O}_{3}$ wire in the resintered $\mathrm{SUS} / \mathrm{Al}_{2} \mathrm{O}_{3}$ composite wire was measured to estimate the distribution of the mechanical properties, and to investigate the influence of the sheath material on this distribution.

\section{Results and Discussion}

\subsection{Vickers Hardness}

The formability of the CFF- $\mathrm{Al}_{2} \mathrm{O}_{3}$ wire has shown to be governed by the reduction in area, the shear strength of the sheath material, and the dimensions of the presintered $\mathrm{Al}_{2} \mathrm{O}_{3}$ billet ${ }^{15)}$. Among these parameters, the reduction in area is determinative to form a homogeneous green microstructure, and has significant influence on the densification behavior and the mechanical properties. Fig. 1 shows the Vickers hardness of the CFF- $\mathrm{Al}_{2} \mathrm{O}_{3}$ wire increases with increase in the reduction in area, and achieves 1800 (i.e. $18 \mathrm{GPa}$ ) at $98 \%$ RA, whereas it is lower than 1300 at $62 \%$ RA. This obvious decrease in the Vickers hardness is attributed to the inhomogeneous resintered microstructures of the CFF$\mathrm{Al}_{2} \mathrm{O}_{3}$ wires with lower reductions in area, especially to the residual pores. After being resintered at $1573 \mathrm{~K}$ for $1 \mathrm{~h}$, the final relative density was nearly $99 \%$ TD for the case of 98\% RA, while it was only $92 \%$ TD for the case of $62 \%$ $\mathrm{RA}$ on the same resintering conditions $\mathrm{s}^{10}$. It means that porosity in the latter one is nearly 4 times as much as that in the former one. Fig. 2 shows the resintered microstructure of the CFF- $\mathrm{Al}_{2} \mathrm{O}_{3}$ wire with $62 \% \mathrm{RA}$, in which continuous and larger pores are clearly observed.

Especially, a few of sharp cusps (indicated by arrows) around the irregular pores have been found in this porous

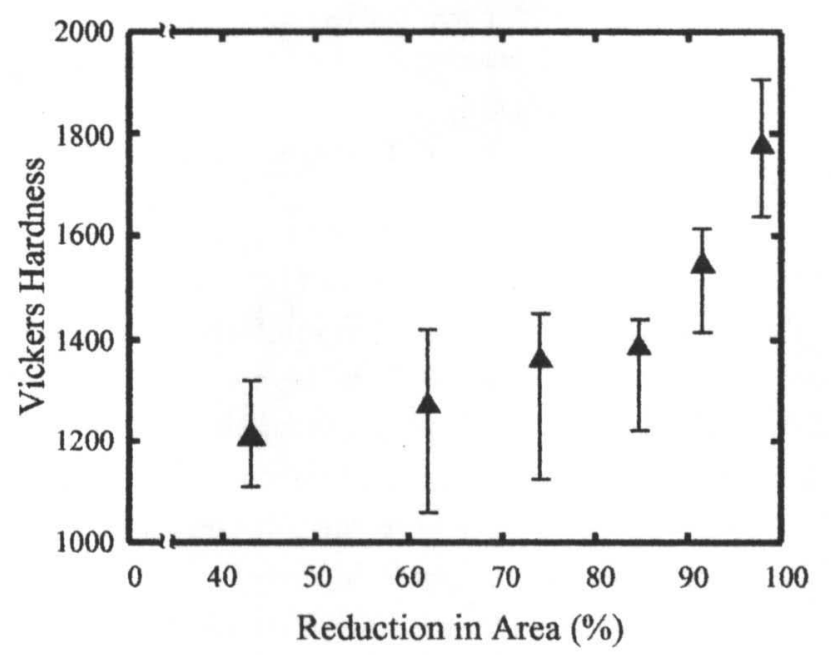

Fig.1 The Vickers hardness of the CFF- $\mathrm{Al}_{2} \mathrm{O}_{3}$ wire as a function of reduction in area.

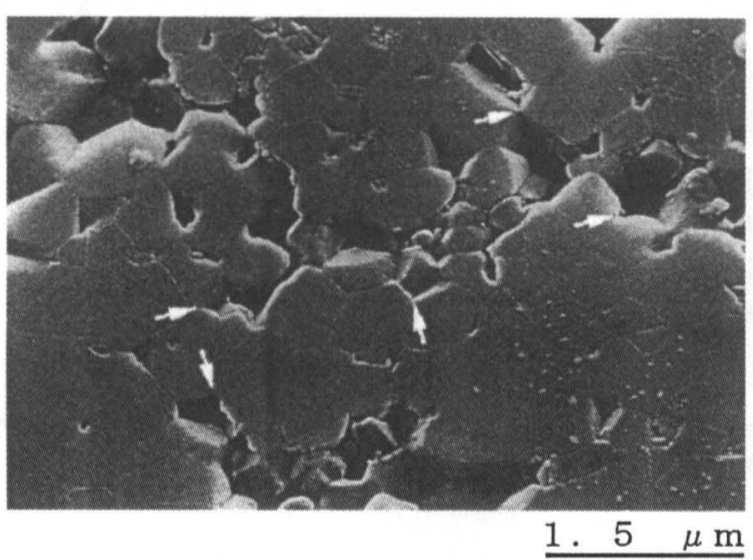

Fig.2 The resintered microstructure of the $\mathrm{CFF}-\mathrm{Al}_{2} \mathrm{O}_{3}$ wire with $62 \%$ reduction in area. 
microstructure. These cusps on the indented surface are easy to make the extension of indentation due to the extremely localized stress when a small load is pressed for a short time $(4.9 \mathrm{~N}, 15 \mathrm{~s})$. Therefore, it is suggested that the residual pores in the final microstructures have a significant effect on the Vickers hardness of the CFF- $\mathrm{Al}_{2} \mathrm{O}_{3}$ wire, and as high as possible reduction in area, such as $98 \% \mathrm{RA}$, is required to result in a homogeneous microstructure without obvious larger pores.

In order to further estimate the effect of the resintered microstructure on the Vickers hardness, the $\mathrm{CFF}-\mathrm{Al}_{2} \mathrm{O}_{3}$ wire with $98 \% \mathrm{RA}$ was resintered at various temperatures and times to yield a range of porosities and grain sizes. Fig. 3 shows the Vickers hardness linearly increases with decrease in porosity and achieves 2100 at $0.5 \%$ porosity (resintered at $1673 \mathrm{~K}$ for $1 \mathrm{~h})$. It is even higher than that (1940) of hotpressed $\mathrm{Al}_{2} \mathrm{O}_{3}$ at $1873 \mathrm{~K}$ for $1 \mathrm{~h}^{16}$. Fig. 4 shows the Vickers hardness of the CFF- $\mathrm{Al}_{2} \mathrm{O}_{3}$ wire as a function of grain size (the porosity of all samples were controlled to be lower than $1.5 \%$ ). It indicates that the variation of the Vickers hardness is not evident as the increase in grain size. This result is in agreement with that reported by Skrovaneka and $\mathrm{Bradt}^{16}$. They concluded that the microhardness of the hot pressed $\mathrm{Al}_{2} \mathrm{O}_{3}$ was independent on grain size on the condition of grain size smaller than $4 \mu \mathrm{m}$. Other studies have also suggested that grain size influence should decrease and finally disappear when it became smaller than a critical value ${ }^{17)}$. The results obtained in the present investigation demonstrate that the Vickers hardness of the CFF- $\mathrm{Al}_{2} \mathrm{O}_{3}$ wire is insensitive to grain size on the condition of grain size smaller than $2 \mu \mathrm{m}$ (see Fig. 4). Therefore, it is suggested that the Vickers hardness of the $\mathrm{CFF}-\mathrm{Al}_{2} \mathrm{O}_{3}$ wire is mainly controlled by porosity, rather than by grain size.

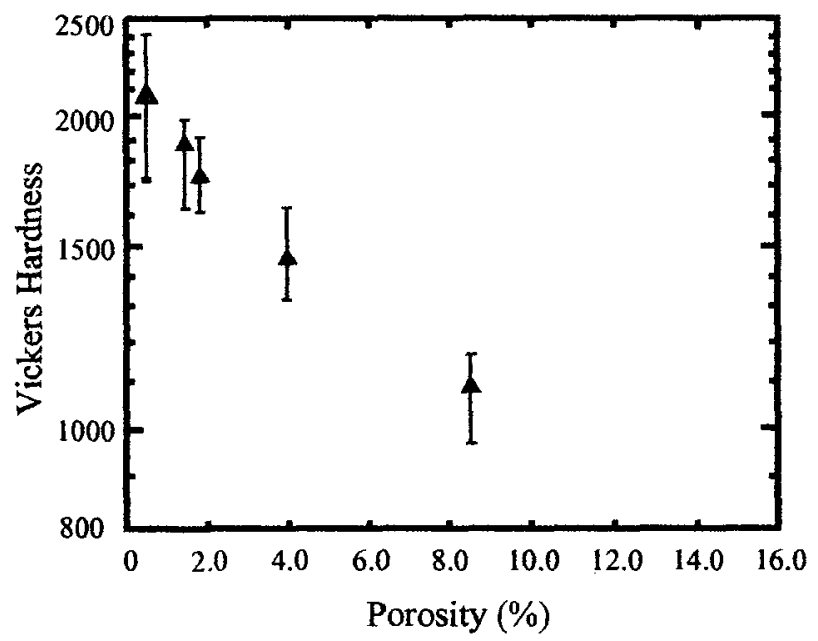

Fig.3 The porosity dependence of the Vickers hardness of the CFF$\mathrm{Al}_{2} \mathrm{O}_{3}$ wire with $98 \%$ reduction in area.
When the $\mathrm{CFF}-\mathrm{Al}_{2} \mathrm{O}_{3}$ wire is used to reinforce the MMCs, it is required to be uniform in mechanical properties. In order to investigate the influence of the sheath material on the homogeneity of the mechanical properties of the CFF$\mathrm{Al}_{2} \mathrm{O}_{3}$ wire, the resintered $\mathrm{SUS} / \mathrm{Al}_{2} \mathrm{O}_{3}$ composite wire was used to measure the distribution of the Vickers hardness. Fig. 5 shows the Vickers hardness on the cross section of the $\mathrm{CFF}-\mathrm{Al}_{2} \mathrm{O}_{3}$ wire at three positions, $20 \%, 50 \%$ and $80 \%$ of the length along the longitudinal direction of the wire, (ten wires have been measured, but only four of them are shown for clearness). It ranges from 1700 to 2200 at each position, but their average values are nearly the same. It implies that the wire is possibly uniform in Vickers hardness along the longitudinal direction (the uniformity of other mechanical properties can also be deduced). In Ref. 15, it

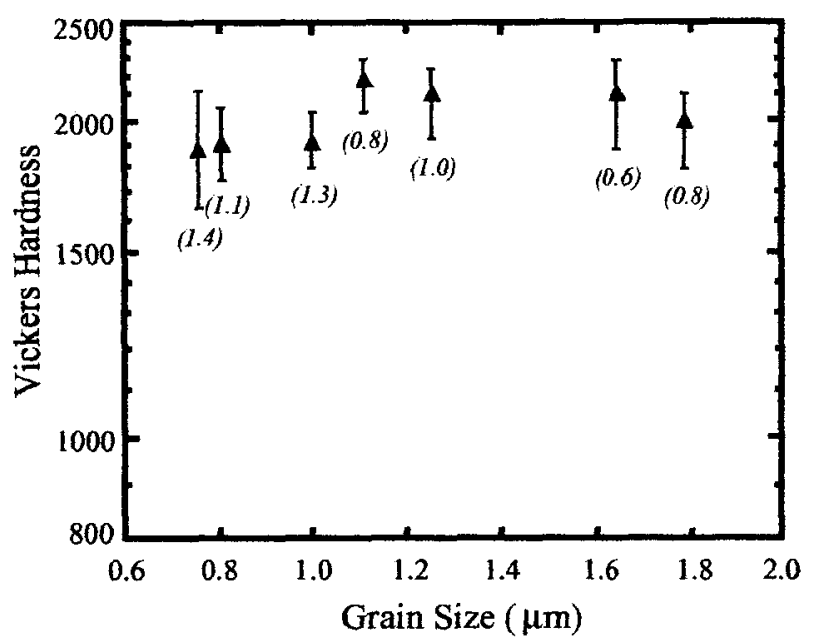

Fig.4 The grain size dependence of the Vickers hardness of the $\mathrm{CFF}-\mathrm{Al}_{2} \mathrm{O}_{3}$ wire with $98 \%$ reduction in area (the data in parentheses are porosity).

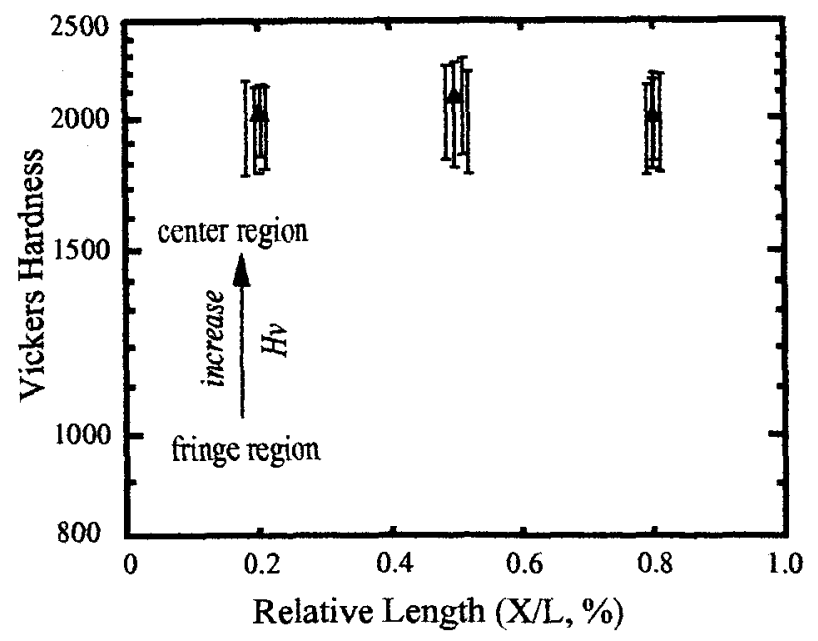

Fig.5 The Vickers hardness of the CFF- $\mathrm{Al}_{2} \mathrm{O}_{3}$ wire at various positions along the longitudinal direction of the resintered SUS $/ \mathrm{Al}_{2} \mathrm{O}_{3}$ composite wire. 
has been confirmed that the green cold-swaged $\mathrm{Al}_{2} \mathrm{O}_{3}$ wire is homogeneous in relative density, diameter and microstructure along the longitudinal direction. They are considered to be responsible for the uniformity of the Vickers hardness after resintering, by which it is thought

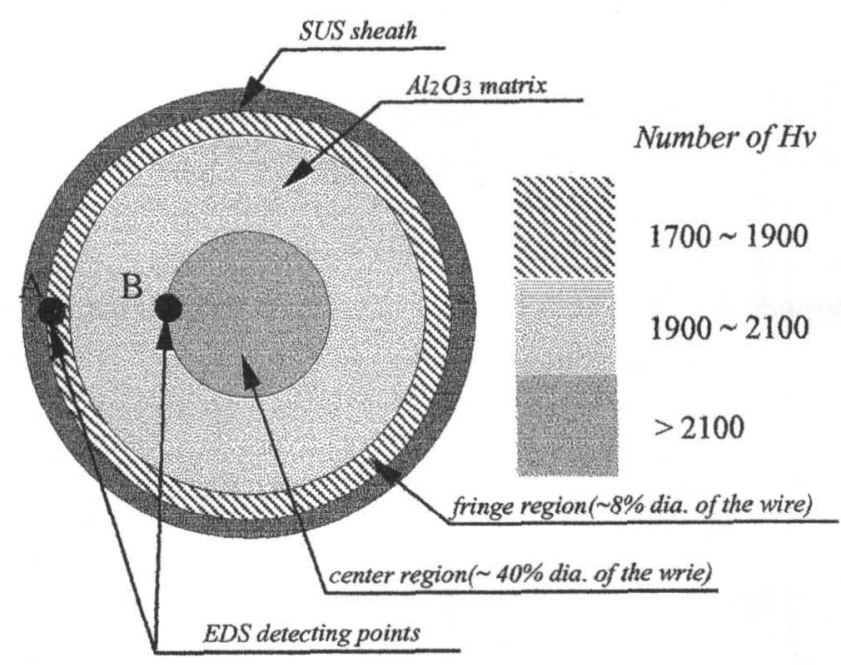

Fig.6 The schematic view of the Vickers hardness distribution on the cross sectional surface of the CFF- $\mathrm{Al}_{2} \mathrm{O}_{3}$ wire in the resintered $\mathrm{SUS} / \mathrm{Al}_{2} \mathrm{O}_{3}$ composite wire.
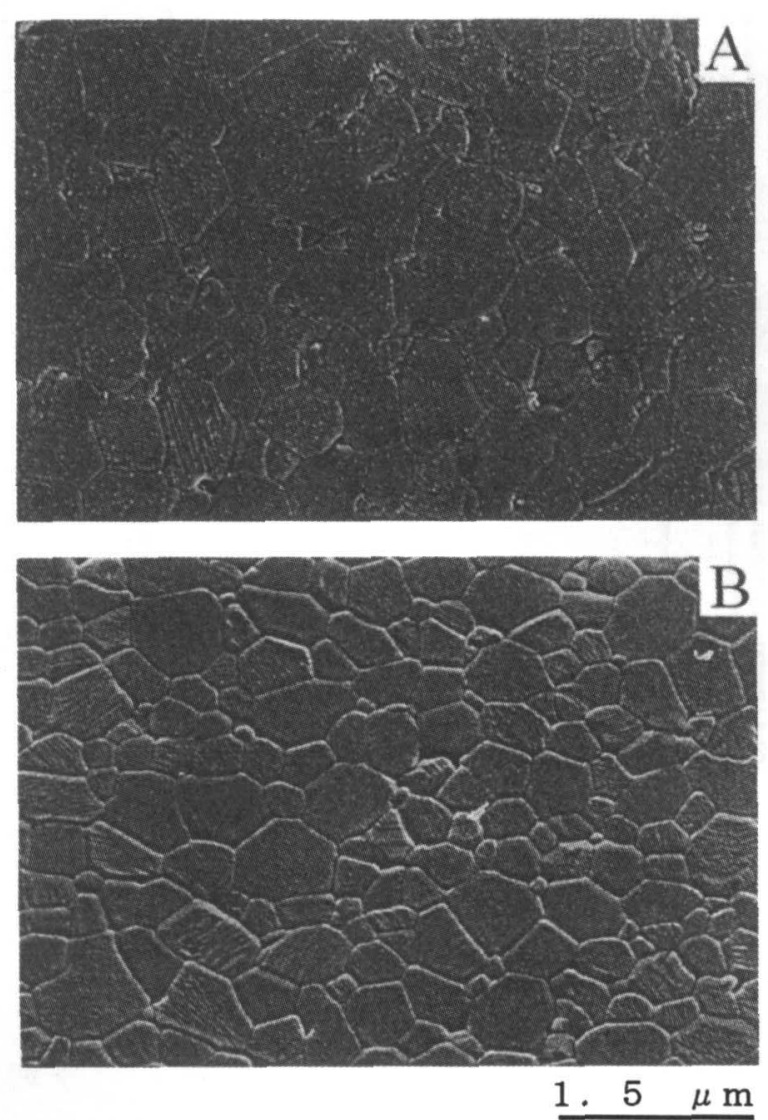

Fig.7 The resintered microstructures of the $\mathrm{CFF}-\mathrm{Al}_{2} \mathrm{O}_{3}$ wire on the fringe region $(\mathrm{A})$ and the center region $(\mathrm{B})$. that the cracks or flaws have not occurred during the resintering process. However, at each position, the Vickers hardness has been found to be higher in the center region, whereas to be lower in the fringe region (see Figs. 5 and 6). This variation on the cross-sectional surface is attributed to the different microstructures in the fringe and the center regions of the wire, which are shown in Fig. 7. The decrease in the Vickers hardness in the fringe region is considered to result from the insufficient densification (a few of pores can be observed in Fig. 7(A)), which is probably attributed to the deposition of impurities from the sheath material during resintering process (it should be noted that the SUS $/ \mathrm{Al}_{2} \mathrm{O}_{3}$ composite wire was resintered). Fig. 8 shows the EDS profiles in the fringe/interface and the center regions of the $\mathrm{CFF}-\mathrm{Al}_{2} \mathrm{O}_{3}$ wire (detecting points are shown in Fig.6). It is clear that the contamination atoms such as $\mathrm{Fe}, \mathrm{Cr}$ and $\mathrm{Ni}$ have been detected out in the fringe region. They might deposit on the pore surface or grain boundary to reduce their energies, hence, to decrease the driving force for densification. However, the EDS profile of the center region indicated that these contamination atoms have not diffused into the $\mathrm{CFF}-\mathrm{Al}_{2} \mathrm{O}_{3}$ wire matrix
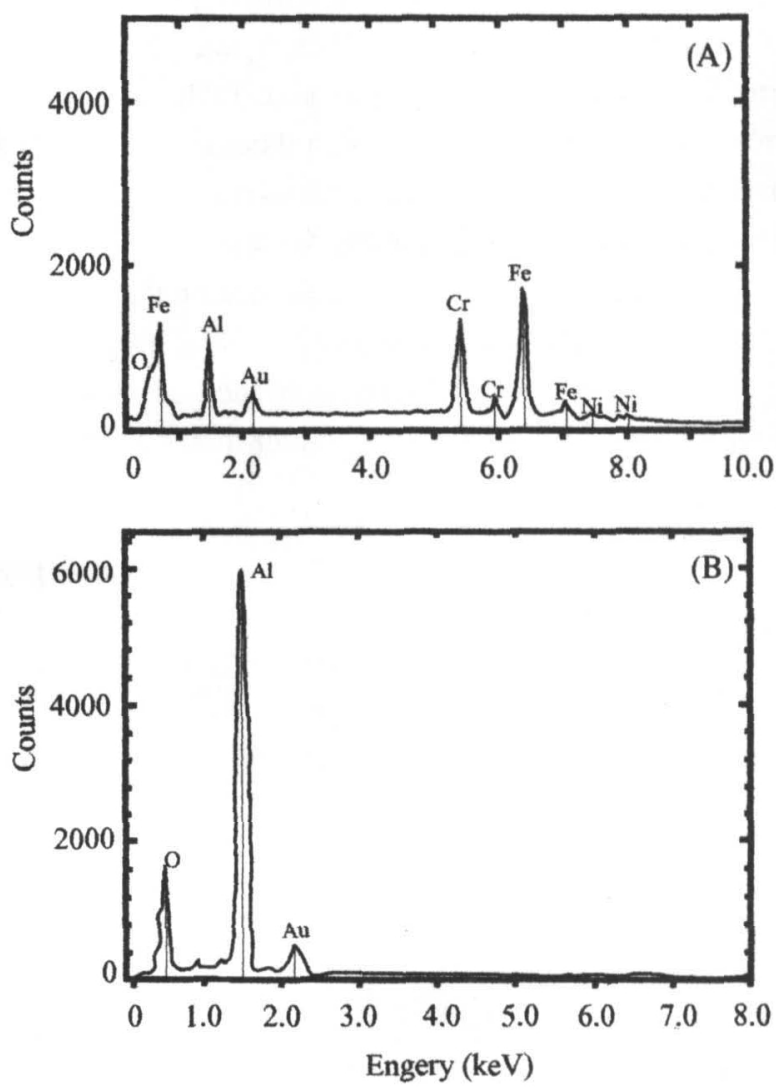

Fig.8 The EDS microanalysis spectra at different positions of the resintered $\mathrm{SUS} / \mathrm{Al}_{2} \mathrm{O}_{3}$ composite wire. (A): the fringe (the interface between SUS material and $\mathrm{Al}_{2} \mathrm{O}_{3}$ wire), (B): the $\mathrm{Al}_{2} \mathrm{O}_{3}$ wire matrix. 
(the presence of Au in Figs. 8(A) and (B) is attributed to the coating on the surface of the samples before SEM observation), by which the higher densification has been achieved in comparison with the fringe region (see Fig. 7 (B)). According to these results, it is considered that the CFF- $\mathrm{Al}_{2} \mathrm{O}_{3}$ wire is uniform along longitudinal direction, but its mechanical properties are reduced in the fringe region, which is due to the contamination from the sheath material during resintering process.

\subsection{Fracture Toughness and Fracture/Tensile Strength}

Fracture toughness is one of the important parameters to predict the mechanical performance of a structural material. High fracture toughness provides high impact-resistant ability of a material. The fracture toughness $\left(\mathrm{K}_{\mathrm{IC}}\right)$ of the $\mathrm{CFF}-\mathrm{Al}_{2} \mathrm{O}_{3}$ wire with $98 \% \mathrm{RA}$ as a function of porosity shown in Fig. 9 indicates two distinct relationships between $\mathrm{K}_{\mathrm{IC}}$ and porosity. In the lower porosity range, $\mathrm{K}_{\mathrm{IC}}$ increases sharply with decrease in porosity, whereas it does slightly in the higher porosity range. The largest $\mathrm{K}_{\mathrm{IC}}$ is about 4.2 $\mathrm{MPam}^{1 / 2}$ at porosity of $0.5 \%$, and trends to achieve about $5.0 \mathrm{MPam}^{1 / 2}$ if full densification is achieved. The point of intersection of these two lines (see Fig. 9), which were yielded by the regression analysis, corresponds to the porosity of about $2.0 \%$. It implies that the extension of indentation is probably controlled by different mechanism for the cases of porosity higher or lower than $2.0 \%$. Cracks around indentation (under a load of $98 \mathrm{~N}$ ) are considered to propagate along grain boundaries in a mode of "pore to pore" for the case of higher porosity, but to extend by cutting through grains for the case of lower one, in which grain boundary may stop the extension of cracks or deflect cracks to prevent them from further extension, hence, to result in high fracture toughness. The 4.2 $\mathrm{MPam}^{1 / 2}$ of $\mathrm{K}_{\mathrm{IC}}$ obtained

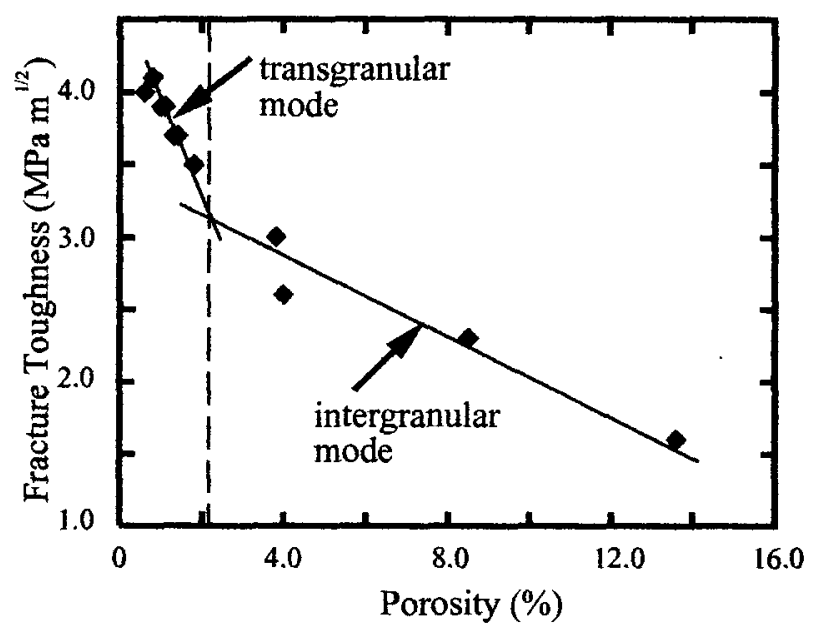

Fig.9 The fracture toughness of the $\mathrm{CFF}-\mathrm{Al}_{2} \mathrm{O}_{3}$ wire with $98 \%$ reduction in area as a function of porosity. in the present investigation is slightly higher than that reported by $\mathrm{Krell}^{\text {s) }}$ where $\mathrm{K}_{\mathrm{IC}}$ of the pressureless sintered $\mathrm{Al}_{2} \mathrm{O}_{3}$ was in the range of 3.7-4.0 $\mathrm{MPam}^{1 / 2}$. The higher $\mathrm{K}_{\mathrm{IC}}$ confirms that the CFF- $\mathrm{Al}_{2} \mathrm{O}_{3}$ wire has an enhanced impact resistant ability, and a high fracture strength is expected.

Fig. 10 indicates the fracture/tensile strength of the CFF$\mathrm{Al}_{2} \mathrm{O}_{3}$ wire with $98 \% \mathrm{RA}$ as a function of porosity. The same behavior as the fracture toughness is observed, by which different fracture modes are considered to control the fracture behavior of the $\mathrm{CFF}-\mathrm{Al}_{2} \mathrm{O}_{3}$ wire at the lower and the higher porosity range. The maximum fracture/ tensile strength of the CFF- $\mathrm{Al}_{2} \mathrm{O}_{3}$ wire is about $1.1 \mathrm{GPa}$, which corresponds to the porosity of $0.5 \%$ and keeps the level of $0.9-1.1 \mathrm{GPa}$ at porosity lower than $2.0 \%$, however, an obvious decrease occurs as the porosity becomes higher than $2.0 \%$. It is only $0.6 \mathrm{GPa}$ when the porosity reaches $13.6 \%$. Fig. 11 shows the fractured microstructures of the CFF- $\mathrm{Al}_{2} \mathrm{O}_{3}$ wire with porosity of $1.4 \%(\mathrm{~A})$ and $8.0 \%(\mathrm{~B})$. In the former one, a lot of cleavage-like appearances have been observed, which indicates that this fracture is dominated by the transgranular mode, viz. by cutting through grains. The fracture origins for this case are considered to be the flaws or voids on the surface of the wire, because the intergranular pores have been fully eliminated. However, the fracture behavior shows to be dominated by the intergranular mude for the case of high porosity (for example, the $8.0 \%$ porosity), viz. the fracture occurs along grain boundary. The fracture origins in this case are considered to be the inner crack-like pores, which have sharp cusps penetrating between grains. These larger

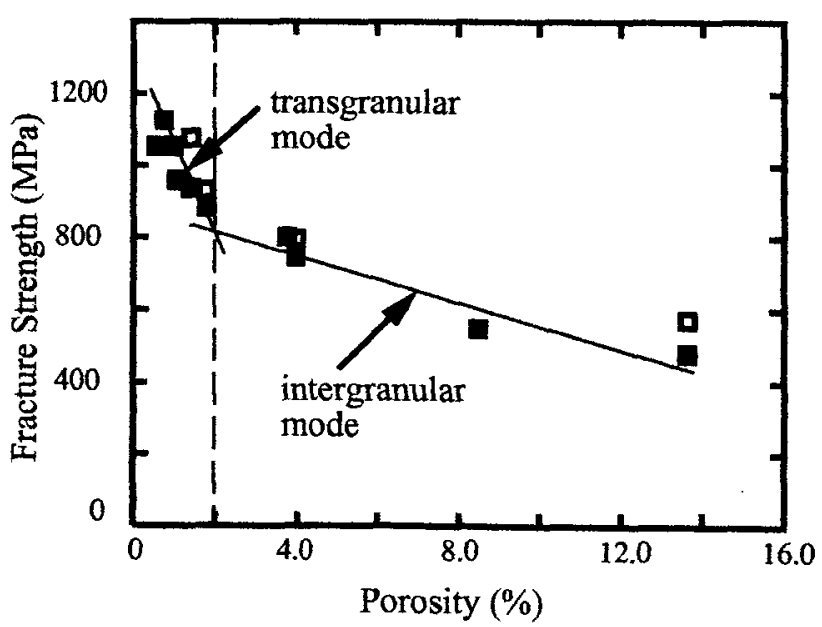

Fig.10 The fracture/tensile strength of the $\mathrm{CFF}-\mathrm{Al}_{2} \mathrm{O}_{3}$ wire with $98 \%$ reduction in area as a function of porosity (open squares represent the data calculated from the fracture/tensile strength of the composite wire, solid squares represent the data calculated from the Vickers hardness). 
cracks will extensively propagate, and easily exceed the critical length at which fracture occurs when a force is loaded on the wire. These results indicate that the fracture of the $\mathrm{CFF}-\mathrm{Al}_{2} \mathrm{O}_{3}$ wire is controlled by the residual porosity: it is the transgranular mode when porosity is lower than $2.0 \%$, and the intergranular mode when porosity is higher than $2.0 \%$.

In addition to porosity, many studies have shown that grain size has a significant effect on fracture strength ${ }^{18-20)}$. The grain size dependence of the fracture/tensile strength of the CFF- $\mathrm{Al}_{2} \mathrm{O}_{3}$ wire shown in Fig. 12 indicates that it monotonically decreases with increase in grain size, but is not precipitous. Usually, the equation describing the relationship between the fracture strength and the grain size of a sintered body is as following ${ }^{18)}$

$$
\sigma_{\mathrm{f}}=\mathrm{K} \exp (-\mathrm{np}) \mathrm{G}^{-\mathrm{m}}
$$

where $p$ is the porosity, $G$ the grain size, $K, m$ and $n$ the parameters determined by materials and microstructures. In order to eliminate the effect of porosity, all samples were controlled to have porosity lower than $1.5 \%$. Hence, the equation 4 can be expressed as
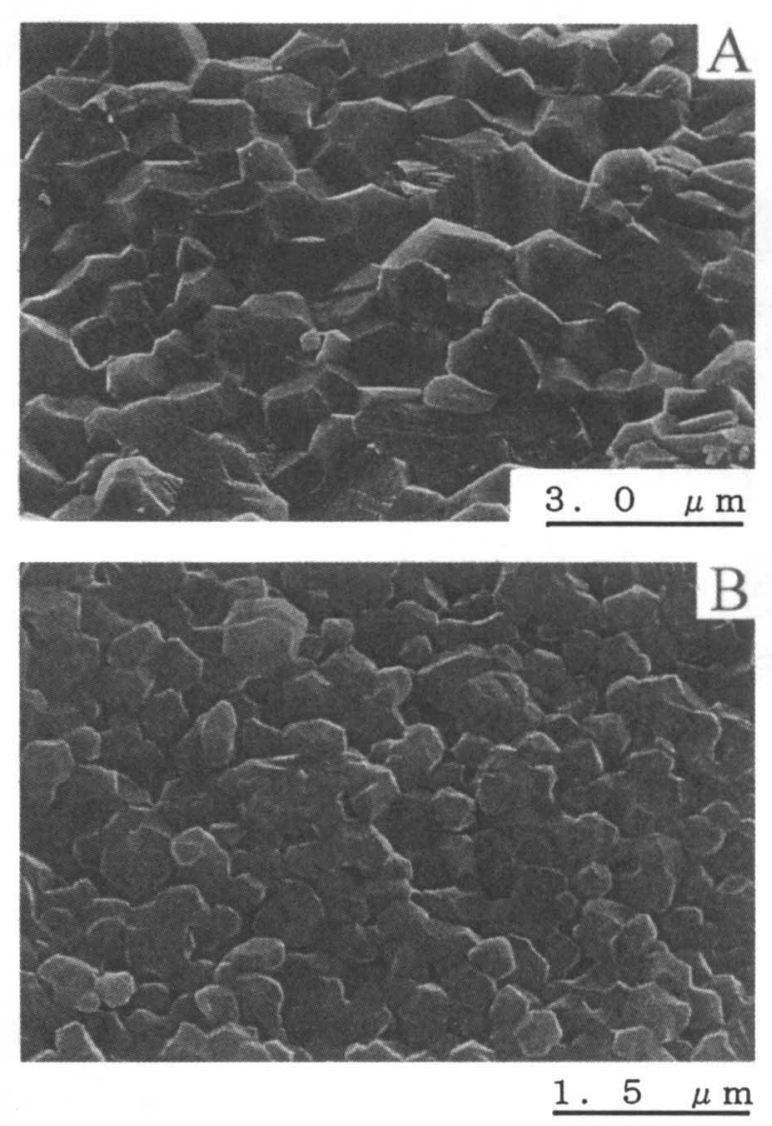

Fig.11 The fractured microstructures of the $\mathrm{CFF}-\mathrm{Al}_{2} \mathrm{O}_{3}$ wire with $98 \%$ reduction in area (A: porosity is $1.4 \%, \mathrm{~B}$ : porosity is $8.0 \%)$.

$$
\sigma_{\mathrm{f}}=\mathrm{K}_{1} \mathrm{G}^{-\mathrm{m}}
$$

The parameter $m$ in equation (5) is calculated to be 0.16 by using the least square method according to the data shown in Fig. 12. This value is smaller than 0.5 reported in the Hall-Petch equation ${ }^{18)}$, which describes that the fracture strength of a metal material has a significant dependence on grain size, especially on abnormal grain size. The results obtained in the present investigation indicate that the grain size dependence of the fracture/tensile strength of the CFF$\mathrm{Al}_{2} \mathrm{O}_{3}$ wire is insensitive. The reason for this insensitivity is considered to be the homogeneous resintered microstructure in which all grains are in the range of 1.0$2.0 \mu \mathrm{m}$. Based on the above discussion, it is suggested that the fracture/tensile strength of the $\mathrm{CFF}-\mathrm{Al}_{2} \mathrm{O}_{3}$ wire should be mainly controlled by the residual pores in the microstructure, rather than by grain size. Therefore, full densification is a determinative requirement to enhance the mechanical properties of the $\mathrm{CFF}-\mathrm{Al}_{2} \mathrm{O}_{3}$ wire.

\section{Conclusions}

Homogeneous $\mathrm{Al}_{2} \mathrm{O}_{3}$ wire with enhanced mechanical properties has been fabricated by the CFF process. The mechanical properties of this wire are mainly controlled by the residual pores in the final microstructure, rather than by grain size. At lower porosity, its fracture is dominated by the transgranular mode and shows high fracture/tensile strength, whereas it is controlled by the intergranular mode and decreases the fracture/tensile strength at porosity higher than $2.0 \%$. The $\mathrm{CFF}-\mathrm{Al}_{2} \mathrm{O}_{3}$ wire is homogeneous in mechanical properties along the longitudinal direction of the wire except a little decrease in the interface due to the

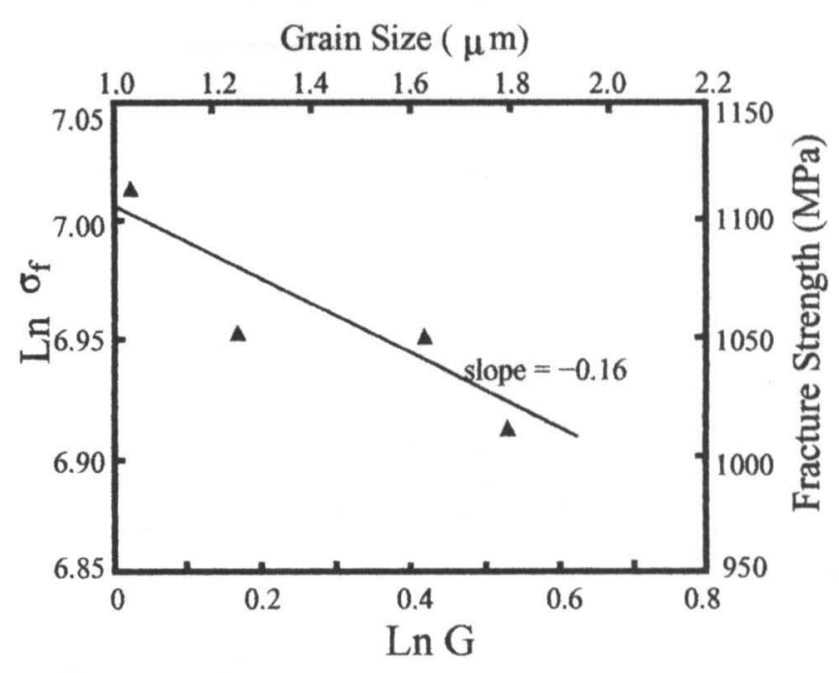

Fig.12 The fracture/tensile strength of the CFF- $\mathrm{Al}_{2} \mathrm{O}_{3}$ wire with $98 \%$ reduction in area as a function of grain size. 
contamination atoms from the sheath material. It is expected that this wire can be used to reinforce metal matrix composites.

\section{Reference}

1) Y.H.Chiou, M.T.Tsai and H.C.Shih: "The Preparation of Alumina Fiber by Sol-gel Processing", J. Mater. Sci., 29(1994)2378-2388.

2) A.K.Dhinger: "Alumina Fiber FP", Phil. Trans. R. Soc. Lond., A 294(1980)411-417.

3) T.Yogo and H.Iwahara: "Synthesis of $\alpha$-alumina fiber from modified aluminium alkoxide precursor", J. Mater. Sci., 27(1992)1499-1504.

4) J.M.Boulton, K.Jones and H.G.Emblem: "Gels, filaments and fibers from alkosysilanes and aluminium chlorohydrate-polyol complexes", J. Mater. Sci., 24 (1989)979-990.

5) A.Krell: "Fracture Origin and Strength in Advanced Pressureless Sintered Alumina", J. Am. Ceram. Soc., 81(1998)1900-1906.

6) H.Mizuta, K.Oda, Y.Shibasaki, M.Maeda, M.Machida and K.Oshima: "Preparation of High Strength and Translucent Alumina by Hot-Pressing", J. Am. Ceram. Soc., 75(1992)469-473.

7) G.Tari, J.M.F.Ferreira, A.T.Fonseca and O.Lyckfeldt: "Influence of Particle Size Distribution on Colloidal Processing of Alumina", J. Europ. Ceram. Soc., 18 (1998)249-253.

8) W.C.Wei, S.J.Lu and C.L.Hsieh: "Colloidal Processing and Fracture Strength of Alumina Prepared from Partially Agglomerated Theta-Phase Powder", J. Ceram. Soc. Japan, 104(1996)277-283.

9) W.B.Du, K.Tatsuzawa, T.Aizawa and J.Kihara: "Densification and Resintering Behavior of Alumina Processed by Controlled Fracture Forming", J. Japan
Soc. Powder and Powder Metal., 45(1998)326-329.

10) W.B.Du, K.Tatsuzawa, T.Aizawa and J.Kihara: "Resintering Behavior of Alumina Compact on the Route of Controlled Fracture Forming", J. Japan Soc. Powder and Powder Metal., 46(1999)125-130.

11) W.B.Du, K.Tatsuzawa, T.Aizawa and J.Kihara: "Grain Growth Behavior of the Alumina Compact by the Controlled Fracture Forming", J. Japan Soc. Powder and Powder Metal., 46(1999)1129-1135.

12) H.Okuta: Engineering Ceramics, Fine Ceramic Technology Series Vol. 6, OHM Press, (1987).

13) D.B.Marshall and A.G.Evans: "Comment on Elastic/ Plastic Indentation Damage in Ceramics: The Median/ Radial Crack System", J. Am. Ceram. Soc., 64(1981)C12-C-14.

14) K.Tatsuzawa, T.Aizawa and J.Kihara: Report on the Controlled Fracture Forming Process, (1998)26.

15) W.B.Du: "Resintering Behavior of the $\mathrm{Al}_{2} \mathrm{O}_{3}$ Wire on the Route of the Controlled Fracture Forming Process", $\mathrm{Ph}$. D thesis, the University of Tokyo, (2000).

16) S.D.Sfrovanek and R.C.Bradt: "Microhardness of a Fine-Grain-Size $\mathrm{Al}_{2} \mathrm{O}_{3}$ ", J. Am. Ceram. Soc., 62(1979) 215-216.

17) A.Krell and P.Blank: "Grain Size Dependence of Hardness in Dense Submicrometer Alumina", J. Am. Ceram. Soc., 78(1995)1118-1120.

18) F.P.Knudsen: "Dependence of Mechanical Strength of Brittle Polycrystalline Speciments on Porosity and Grain Size", J. Am. Ceram. Soc., 42(1959)376-387.

19) H.P.Kirchner and R.M.Gruver: "Strength AnisotropyGrain Size Relation in Ceramic", J. Am. Ceram. Soc., 53(1970)232-236.

20) D.Kovar and M.J.Readey: "Grain Size Distribution and Strength Variability of High-Purity Alumina", J. Am. Ceram. Soc., 79(1996)305-312. 